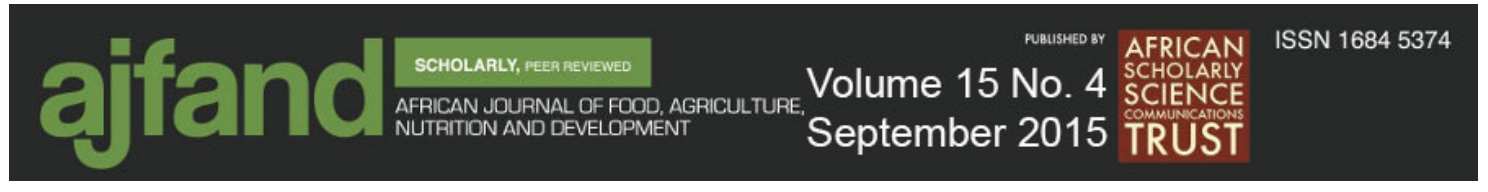

\title{
PLANTAIN, BANANA AND WHEAT FLOUR COMPOSITES IN BREAD MAKING: PROSPECTS FOR INDUSTRIAL APPLICATION
}

\section{TA Adeniji*1}

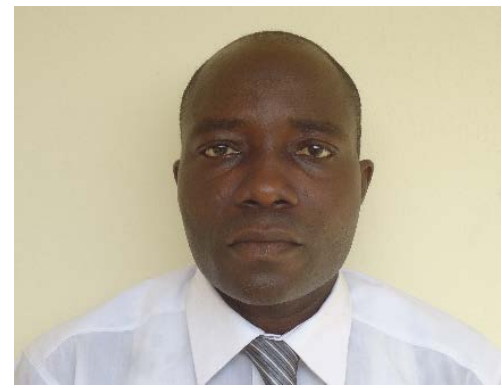

Tajudeen Adeniji

*Corresponding author email: aderisation@gmail.com OR adenijitajudeenadebayo@yahoo.com

${ }^{1}$ Songhaï Rivers State Development Initiative, Km 5, Bunu, Ban Ogoi Road, Tai Local Government Area, Rivers State, Nigeria. 


\section{ABSTRACT}

Bread is one of the most convenient, least expensive and most important staple foods in the world today. It is usually fermented and baked into loaves or cakes. Bread making has been with the Chinese for 5000 years and has also been found in ancient Egyptian tombs and reported widely in the Old Testament of the Holy Bible and in the Holy Qur'an. Bread was introduced to Nigeria probably about two centuries ago either by white colonialists or it may have been acquired from the Arabs through the TransSaharan trade with the Fulanis and Hausas of Northern Nigeria, especially during the eras of Mali and Songhaï Empires. Wheat bread is widely consumed in all parts of Africa. Research into the use of indigenous raw materials in the production of composite bread, cakes and confectionery products has been carried out in several African research institutes and universities. These investigations have proven beyond doubt the baking potentials of various tropical crops including plantain and banana. Improved varieties of plantain and banana have been developed and widely distributed to farmers in West and Central Africa as well as East and Southern Africa by the International Institute of Tropical Agriculture (IITA). This effort was complemented by extensive post-harvest research on new product development and evaluation from various accessions of plantain and banana hybrids. Transformation of fruits at different stages of ripening involving different processing techniques, packaging and preservation of new products was disseminated to farmers and food processors. This was necessary to add value to fresh plantain and banana, reduce post-harvest loss, enhance product diversification and provide jobs. Despite these approaches, there has been limited effort to implement composite bread technology in developing countries at the industrial level. This paper is a review of the application of tropical crops, especially plantain and banana in bread making. Output of this review may provide impetus for sustainable adoption of nonwheat or composite wheat bread making technology in Africa.

Key words: Plantain, wheat, baking, composite, bread, banana, postharvest, industrial, evaluation, adoption 


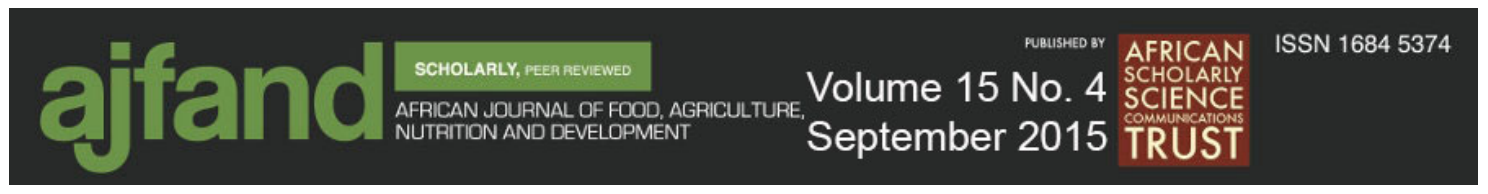

\section{INTRODUCTION}

The uses of plantain or banana and wheat flour in composite bread, cakes and biscuits have been widely reported [1, 2, 3, 4]. The most popular yeast-leavened product is bread, which usually comes in an array of sizes, shapes, textures, and tastes and is widely consumed globally. For example, bread varies in size from small bread sticks to loaves weighing several kilos. Crust, colour and texture can vary from the thick, black crust of pumpernickel to the thin, white crust of Chinese steam bread. The reasons for the large variations are complex and difficult to explain [5] and many of them have to do with tradition, how much of the diet is bread, and other factors. Bread is a food product made of flour or meal that is moistened, kneaded and sometimes fermented [6], and then usually baked into loaves or cakes [7]. Bread is a universally accepted, convenient form of food for all populations, rich and poor, rural and urban [8]. It was introduced to Nigeria probably about two centuries ago [9].

Wheat suitable for bread making is produced in commercial quantities in temperate countries such as Canada, Australia and countries in the former USSR [10]. Production of bread from plantain and banana flour could help to reduce wheat importation and consequently help importing nations to harness the use of locally produced raw materials and save their currency. Nigeria's investment in wheat importation from 1999 to 2010 amounted to $\$ 1,087$ trillion, and in 2010 alone, 3,971,861 tons of wheat was imported, which amounted to $\$ 1,044,982$ [11]. Wheat contains a protein, gluten, which when mixed with water and worked by mechanical action, forms an elastic dough, which consequently imparts to leavened bread its unique and much-desired texture.

The cost of most widely consumed types of wheat breads in Nigeria ranges between $\$ 50$ to 350 depending on their size, which is on the high side considering the poor masses that depend largely on bread loaves as their major staple food. This, therefore, gives impetus for further research into the use of composite flour for baking. A motivation of this review process was not as a result of paucity of information required for the implementation strategy for industrialisation of plantain and banana flour in composite baking venture, but due to lukewarm attitudes of bakers in adopting the composite flour baking technology. This review was, therefore, carried out to provide an assemblage of available data to stimulate policy makers and industrialists on the need for plantain and banana composite baking technology in Africa.

\section{IMPORTANCE OF WHEAT IN BREAD MAKING}

Wheat (Triticum spp.) is the world's leading grain crop, whose importance is derived from the physical and chemical properties of the gluten, which make possible the production of leavened bread [12]. Apart from its use in bread making, wheat also finds wide application in pastry and semolina products, and for fermentation to make alcoholic beer [13] and vodka, [14] or biofuel [15]. The wheat plant is fairly hardy and can grow under a wide variety of environmental and soil conditions [5]. Many people like wheat-based products because of the taste, and particularly the texture. Wheat is unique among cereals because its flour possesses the ability to form a visco-elastic dough when mixed with water. 
Leavened bread from wheat flour has been eaten in the Mediterranean Basin for at least 3000 years [10]. Baked goods such as bread, cakes and meat pie are particularly pleasing foods with numerous advantages over other staple foods. For instance, they are extremely convenient because further preparation is not required once purchased. The products are superior in nutritional quality, particularly the protein and vitamin contents, when compared to staple foods such as rice, potatoes, bananas and cassava. Bread is rarely eaten alone when compared to other staple foods. For example, in the sandwich form, bread acts as a platform for consumption of high protein products such as meat, cheese and vitamin-rich foods. Moreover, bread is superior in that it is a solid that can easily be carried, and it forms an ideal material for enrichment with vitamins, minerals and protein concentrates. It would seem probable, therefore, that any community could, with considerable benefit to health, increase its consumption of bread, including those produced from plantain and banana flour.

\section{“HARVEST PLUS” GLOBAL CHALLENGE PROGRAMME ON NUTRITIONAL ENHANCEMENT AND BIODIVERSITY OF PLANTAIN AND BANANA}

The Consultative Group on International Agricultural Research (CGIAR) initiated a nutritional enhancement project in 1995 to improve the micronutrient components of certain crops including plantain and banana, rice, wheat, maize, phaseolus beans and cassava with a focus on iron, zinc and vitamin A. It is estimated that 75 to 251 million children have sub-clinical symptoms of vitamin A deficiency worldwide [16, 17]. Nutritionally-improved crop varieties are easily adopted by rural communities when compared with supplementation, fortification and dietary diversification or modification. In terms of nutritional value, plantain contains 1,127 IU/100g of vitamin A and 457 $\mu \mathrm{g} / 100 \mathrm{~g}$ of $\beta$-carotene against $9 \mathrm{IU} / 100 \mathrm{~g}$ of vitamin $\mathrm{A}$ and $5 \mu \mathrm{g} / 100 \mathrm{~g}$ of $\beta$-carotene in wheat [18]. Also in plantain, the potassium content of $499 \mathrm{mg} / 100 \mathrm{~g}$ exceeds the 363 $\mathrm{mg} / 100 \mathrm{~g}$ in wheat [18]. The Nigerian government has mandated food manufacturers to fortify their products with essential minerals and vitamins. However, such food supplements and fortified products are beyond the reach of many households in Nigeria and other developing countries due to their high cost. International Institute of Tropical Agriculture (IITA), a key member of CGIAR is combating micronutrient deficiency in its mandated crops, which includes plantain and banana, cassava, yam, and maize through genetic manipulations. The use of micronutrient-rich varieties has the potential for sustainable impact on the nutritional status through the promotion of high pro-vitamin A carotenoids. Previous works reported that Micronesian banana varieties have a high level of carotenoids that is capable of providing up to half of the total daily vitamin A requirements in a single fruit $[19,20]$. In developed countries, $70-90 \%$ of carotenoid intake is derived from fruits and vegetables, and provide about $25-35 \%$ of the total retinol intake, whereas in developing countries, this contribution can be as much as $82 \%$ [21]. This strongly suggests that there is real potential for improving human nutritional status and achieving long-term population health benefits without enforcing a change in dietary eating habits. New plantain and banana hybrids may potentially be applied in intervention programmes to combat nutritional deficiencies through the application of flours derived from green unripe fruits for baking and confectionery products manufacturing. 
The production of plantain and banana is increasing following the distribution and acceptance of disease resistant and high yielding varieties in the West and Central Africa (WCA) and East and Southern Africa (ESA) produced by IITA. Processing of plantain and banana into high quality, easy-to-use flour is anticipated to increase their economic importance [22]. These factors provide impetus for increasing plantain and banana utilisation in various product formulations, especially in high quality flour production for the baking industry.

\section{CONSTRAINTS TO COMPOSITE BREADMAKING}

The major problem with bread consumption in Africa is that most countries cannot produce sufficient quantities of wheat required by the baking industry. In Angola, Cameroon, Côte d'Ivoire, Ghana, Guinea, Madagascar, Mozambique, Nigeria, Tanzania, Uganda and Zaire, about 2 million tons of wheat are imported for the baking industry annually, and local wheat production is less [23]. Nigeria imports the most food, with grains being the key produce, when compared against other West African countries; these imports account for 36\% of Economic Community of West African States (ECOWAS) food imports [24]. Rice and wheat are also imported into Nigeria in large quantities with a significant deficit in the production of these two commodities. Plantain production increase at an average rate of between $2.3 \%$ to $2.6 \%$ in West Africa [25] could be harnessed to further boost production for industrial application. Nigeria is the third largest producer of banana in the world with annual production of 1.9 million tonnes [26]. The development and dissemination of disease resistant, high yielding varieties of plantain and banana by IITA had evolved, thus, increasing the amount of these crops being harvested annually.

One of the technical constraints militating against the supplementation of wheat with non-wheat flours is the replacement of the unique functional viscoelastic properties of the main functional wheat protein (gluten) [27]. When gluten is mixed with water and worked by mechanical action, it forms elastic dough, which may be stretched in two directions and form sheets or films [28]. The properties of a dough or batter depend considerably upon the type of flour used. Strong flours containing more gluten and gluten of a quality that will stretch farther before tearing are the kind chosen for making bread because bread dough must be able to expand to a great degree and yield baked products of especially light density. Weaker flours, however, contain less gluten and their films are less tough and tear more readily and when baked, yield structures that are less chewy but tenderer. However, attempts have been made to partially replace strong wheat flour at different levels of substitution in bread making. Such composite bread usually requires at least $70 \%$ of wheat flour to be able to form leavened products [29, 30].

\section{PROSPECTS FOR PLANTAIN AND BANANA FLOUR COMPOSITE BREAD}

Plantain production in Nigeria is estimated at about 2.4 million metric tons, which are mostly obtained from the southern states [31]. This accounts for its wide use in diverse ways alongside other staple foods crops in Nigeria. The increasing consciousness for consumption of healthy foods (as prevention is better than cure) has been a major force 
driving the demand for healthy foods like plantain flour in Nigeria. The demand for plantain flour has been estimated to be in excess of 100,000 tonnes per annum [32]. The current supply level is less than $20 \%$ of the estimated demand with only few companies producing on mechanised commercial scale. Popular brands of plantain flour in the Nigerian market include Lemmy, Inutech, Ayoola, Bil, Amazing, DSC and Deluxe. Plantain, the only raw material required for the production of plantain flour is available in commercial quantities in fourteen major plantain and banana growing states in Nigeria, including Edo, Delta, Ondo, Rivers, Cross River, Akwa Ibom, Imo, Abia, Ogun, Oyo, Osun, Anambra, Enugu and Lagos [32]. Plantain is rich in dietary fibre and resistant starch and it is a good source of carotene, vitamin B complex (thiamine, niacin, riboflavin, and B6), vitamin $\mathrm{C}$, and micronutrients [33, 34]. The average variable cost of plantain per dozen in Nigeria is $\$ 4$, 255, while the average total revenue per dozen of plantain bunch is $\$ 6,962$ with a gross margin of $\$ 2,708$ [35]. This shows that plantain marketing is a profitable venture, in conformity with a previous finding [36]. Several studies have been carried out to either replace or substitute indigenous food crops for wheat in baking [1, 2, 3, 4, 37]. To complement research efforts in achieving composite baking technology, a ban was placed on importation of wheat into Nigeria by the Nigerian Government in 1987, which highlights the need for marketable composite bread. Technically, organoleptically acceptable cakes were developed from 100\% flour of two different cultivars of cooking bananas (Cardaba and Bluggoe) by Adeniji and Empere [2]. Cardaba had the highest energy content (360.4 KJ/100g), while wheat and Bluggoe had $356.2 \mathrm{KJ} / 100 \mathrm{~g}$ and $344.5 \mathrm{KJ} / 100 \mathrm{~g}$, respectively. Also, breads and biscuits formulated from 80:20 and 60:40 (w/w) (wheat:plantain) levels of substitution for breads and biscuits, respectively were technically feasible and organoleptically acceptable to consumers [4]. Sarawong et al. [38] incorporated green plantain flour into rice flour and wheat starch as a functional ingredient to produce gluten-free bread. In these trials, an addition of up to $30 \%$ green plantain flour resulted in acceptable bread quality with maximum resistant starch content. In a study on composite bread making, different levels of cowpea and plantain flours were mixed with wheat flours to determine the quality of bread so produced [39]. Plantain flour was uniquely processed by blanching at $100^{\circ} \mathrm{C}$ in hot water for two minutes, which increased final viscosity, reduced rapidly available glucose and increased bread loaf size. Cowpea was also uniquely processed by soaking, drying, brushing, and then de-hulled. The hulls were incorporated to provide fibre and phytonutrients. These flours can be incorporated into wheat flour bread up to $20 \mathrm{~g} / 100 \mathrm{~g}$ with improved physical properties and possibly better glycemic responses. Research has also revealed that blanching changed the proximate composition, pasting properties of plantain [40]. Dry heat and moist heat processing of plantain altered the physical form of the carbohydrates and affected amylase digestion [40], while Adeniji et al. [41] showed that blanching and cold water treatment reduced sugar and protein content of plantain flour. Supplementary effect of plantain flour on dough characteristics and bread quality was investigated by Ehirim and Umelo [42], which revealed that acceptable bread could be produced from wheat/plantain composite flour at up to $15 \%$ plantain flour substitution. Adepoju et al. [43] processed plantain into various products by sun drying, fermentation, boiling, and roasting. The low sodium content of the products makes them suitable for hypertensive people while the low carbohydrate content coupled with relatively high energy makes them suitable for consumption by diabetics. Eke-Ejiofor and Kiin-Kabari [44] investigated composite bread formulation using different levels of 
wheat flour substitution with plantain flour (0-50\%), including 100\% wheat flour and $100 \%$ plantain flour. The research showed that all sensory attributes reduced as substitution increased with the $10 \%$ substitution of plantain flour having no significant difference in colour and taste, while texture and overall acceptability were significantly different between all the samples. It is highly encouraging that no panelist showed a total dislike for any of the composite bread samples, except the bread sample made from $100 \%$ plantain flour. The researchers, therefore, concluded that wheat flour could be substituted with up to $20 \%$ (w/w) plantain flour without adversely affecting the nutritional and sensory properties of leavened bread. Plantain and banana products are also used as foods, beverages, fermentable sugars, medicines, and flavourings [45]. In his studies on the baking potentials of plantain flour and pulp, Ogazi [1] reported that good quality bread could be produced by substituting wheat flour with up to $15 \%$ of either plantain flour or plantain pulp. Also, plantain Maidera cakes can be produced by substituting wheat flour with up to $50 \%$ of plantain flour and $40 \%$ of plantain pulp [1]. Despite these efforts, there has been very limited or no industrial implementation of the composite bread technology in developing countries. This may probably be due to lack of government intervention, inadequate information on the economic and health benefits as well as lukewarm attitude of policy makers to composite bread making technology.

Looking at the extensive research on the use of plantain and banana flour in composite bread making, there is potential for application of Musa spp flour in the baking industry. In their studies on the use of plantain and soy flour substitution in wheat, Olaoye et al. [3] reported that the nutritional qualities and sensory attributes of plantain floursubstituted breads are comparable to those of whole wheat bread. These authors, therefore, recommended that up to $15 \%$ plantain flour substitution could be adopted in bread making processes without adverse effects on quality. Juarez-Garcia et al. [46] studied the composition, digestibility and application of banana flour in bread making and reported a glycaemic index of $65.08 \%$ for banana bread and $81.88 \%$ for wheat bread. This shows that banana flour is a potential ingredient for bakery products containing slowly digestible carbohydrates. Banana bread can, therefore, be used as dietary aid by people with special low caloric requirements. The blood glucose responses of carbohydrate foods can be classified by the glycaemic index (GI), which is considered to be a valid index of the biological value of dietary carbohydrates, and it is the measure of the potential of carbohydrate to raise blood glucose concentration after a meal [47]. In simple terms, carbohydrates that break down quickly during digestion have a high glycaemic index because blood glucose response is fast and high, while those that break down slowly have a low glycaemic index [48]. Many traditional starchy staple foods have low glycaemic indices and they include whole-grain pumpernickel breads, cracked wheat or barley, parboiled rice, dried peas, beans, pasta and lentils [49]. Consumption of these products should constitute part of the general advice for healthy eating rather than a detailed discussion of individual food values [50]. In 1999, the World Health Organisation (WHO) and Food and Agriculture Organisation (FAO) recommended that people in industrialised countries base their diets on low-GI foods in order to prevent the most common diseases such as coronary heart disease, diabetes and obesity [38]. The glycaemic index values have a large inter- and intra-individual variability [51]. Studies on altering GI and glycaemic load have indicated that the lower the GI and glycaemic load of the first meal, the less food consumed in the subsequent meal [43]. 
The modified noodle product described by Saifullah et al. [52] may broaden the range of low glycaemic index foods and increase innovation of products from banana flour. Banana pulp noodles were prepared by partial substitution of wheat flour with green Cavendish banana pulp flour resulting in lower glycaemic index when compared to the control noodles. Some of the economical strategies to increase banana flour utilisation include production of banana flour and to incorporate the flour into various innovative products such as slowly digestible cookies [53], high fibre bread [46] and edible films [54]. The numerous advantages presented by green banana flour include high total starch, resistant starch, and dietary fibre content [46]. Due to the high content of these functional ingredients, commercial production of bakery and confectionery products from banana flour is expected to confer beneficial human health advantages [55]. Since low glycemic index foods release glucose at a slower rate, banana pulp that contains high amount of resistant starch and dietary fibre have potential to slow the rate of starch hydrolysis in bakery products. The amount of crude fibre in plantain flour may influence the digestibility of products made from it, including bakery and confectioneries [56]. This may, therefore, help to maintain the normal internal distention of the intestinal tract and thus, aid digestion of processed foods.

In another study, Abiodun and Adeleke [57] reported on substitution of banana flour with soybean flour to improve the protein content of the flour. Substitution of up to $20 \%$ of soybeans produced dough with comparable quality to un-substituted banana flour dough. This will consequently improve, especially the baking potential of banana flour. It has also been reported that the addition of defatted okra seed flour to plantain flour resulted in increased protein content and reduction in the fat content [58]. Fibre and ash content of the flour also increased suggesting that nutrients become more available in the food prepared from the plantain flour, including bakery and confectionery products.

In the past, bread is seldom made from any other crop other than wheat, hence the term 'wheaten bread'. Composite flours are mixtures of non-wheat flours with or without addition of wheat flour. Non-wheat flours may include flours or starches prepared from roots, tubers, cereals, and oil seeds. The demand for bread and other baked goods is increasing globally. In Nigeria, baked goods such as cakes and biscuits and pies enjoy a rapidly increasing popularity, the commonest being bread [1, 37, 59]. In the last three decades, there has been extensive research into the use of indigenous raw materials in the production of composite flour for bread making [60]. Bamidele et al. [37] in their study on rheology and baking potential of wheat and plantain composite flour reported that baking quality decreases with increasing level of supplementation and summarised that breads of acceptable quality can be produced from flour blends of $100 \mathrm{~g} / \mathrm{kg}$ blanched plantain flour with $900 \mathrm{~g} / \mathrm{kg}$ of wheat flour. The plantain flour used was produced by blanching the pulp in $1 \mathrm{mg} / \mathrm{L}$ of sodium metabisulphite solution at $70^{\circ} \mathrm{C}$ for $3 \mathrm{~min}$ and dried in an air oven at $70^{\circ} \mathrm{C}$ for $8 \mathrm{hr}$, then milled and sieved through a $0.025 \mathrm{~mm}$ sieve to obtain the same particle size distribution as wheat flour. Plantain and banana flour is currently on sale in several cities in southern Nigeria, which is a strong indication that farmers and plantain processors are beginning to adopt processing options as a means of market diversification. Plantain flour is currently being exploited in baking and complementary weaning foods in Nigeria $[1,61]$. The application of plantain, cassava, 


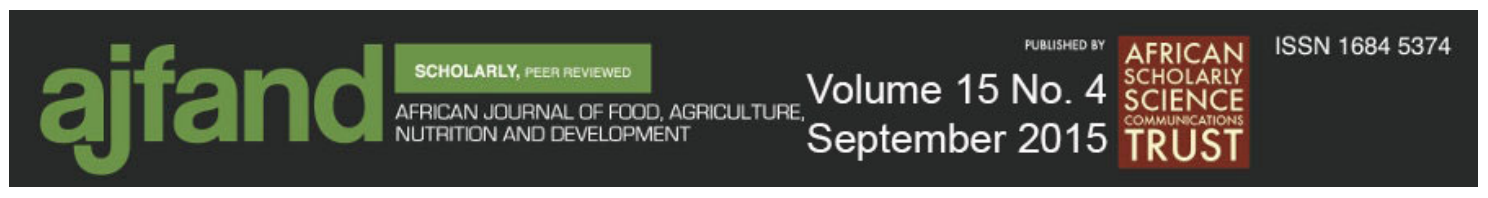

soybean and maize flours has also been exploited in baking [62] and complementary food formulations [61, 63].

Chukwu et al. [63] developed extruded snacks and weaning foods from a cooking cultivar (Bluggoe) in combination with maize and soybean to add economic and nutritive value to the cooking banana, which is considered to be of low value when compared to plantain landraces by consumers. Most of the sensory panelists who evaluated the products found the paste from cooking banana-based weaning food acceptable, but mothers preferred paste made from commercial Cerelac because of its vanilla flavour and taste. In an exploratory work on the use of cheap and locally available staples to improve the Nigerian traditional complementary foods, Baiyeri [61] combined maize, soybean and plantain flour in ratios of 70:30:0, 65:30:5, 60:30:10, and 55:30:15 (protein basis) of maize, soybean, and plantain. The nutrient levels of the composites were compared with Codex Alimentarius Commission Guidelines for formulated supplementary foods for older infants and young children. "Ogi” flour (a traditional pap usually produced from maize) and Nutrend (commercial weaning food) served as the controls. The composites showed nutritional superiority over "ogi" flour in terms of protein, lipid, ash, and iron. Although judges preferred "ogi” and Nutrend, porridges made from the composites were also acceptable organoleptically. In their investigation on sensory characteristics of plantain-wheat biscuits, Sanni and Eniola [62] used plantain-wheat flours in the ratios of 1:0; 0:1; 4:2 and 2:4, and found out that the biscuits did not differ in texture. Taste, crispiness, aroma and overall acceptability of plantainwheat (2:4) and wheat biscuits are similar, while $100 \%$ wheat biscuits were preferred to $100 \%$ plantain biscuits.

Akubor [64] has shown that plantain flour has a good potential for use as a functional ingredient in bakery products on account of its high water absorption capacity. Dupaigne and Richard [65] incorporated 24\% ripe banana flour into wheat flour in the manufacture of Army biscuit (high energy biscuit developed for the military especially while at war front). The ripe banana flour (powder made from ripe banana fruit) was substituted for sugar because of the high sucrose, fructose and glucose content of ripe banana. Ogazi [1] incorporated ripe plantain pulp into the bread dough with the aid of domestic liquidiser, which was applied to produce a fine comminuted slurry used in bread making.

\section{PRINCIPLES OF BAKING AND BREADMAKING PROCEDURES}

The term baking strictly refers only to the operation of heating dough product in an oven. Since there are many steps that must take place if baking is to be successful, in a broader sense, the term baking has come to mean all of the science and technology that must precede the oven as well as the oven-heating step itself [28]. The function of baking is to present flour in an attractive, palatable and digestible form [66].

Bread is made by many different procedures depending on tradition, the amount (cost), the type of energy available, the type and consistency of the flour available, the type of bread desired, and the time between baking and eating [5]. The minimum formula for bread is flour, yeast, salt, and water such that when any of these ingredients is missing, the product cannot be regarded as leavened bread. 
In most parts of the world, leavened bread is consumed within a few hours and most certainly within the first day after it is produced because much of the bread produced may not be edible the day after baking. In the United States, by contrast, bread may not reach the supermarket shelves within the first $24 \mathrm{hr}$ after baking and the bread must remain soft and edible for six to seven days after baking. The outstanding quality of bread wheat grown in the United States may have been largely responsible for this difference in U.S. bread and the bread that is produced in most of the rest of the world [5]. Other countries where wheat of such bread-making quality is produced include Canada, Australia, Argentina, the former U.S.S.R., Hungary, the Middle East, and the Punjab area of India.

\section{CONCLUSION}

Wheat grain is not produced in commercial quantities in Nigeria and, therefore, a large amount of foreign exchange is used yearly for its importation. Research evidence at IITA, Federal Institute of Industrial Research, Nigeria (FIIRO) and other research institutes and universities in Africa has shown that flours made from plantain and banana can be incorporated into wheat flour for bread making at different levels of substitution with 10 $15 \%$ being the most acceptable for leavened bread making, while $15-20 \%$ is acceptable for confectioneries and other non-leavened baked products. Supplementation of wheat flour with high quality flours from improved plantain and banana hybrids with increased levels of micronutrients may constitute an essential package to complement plantain and banana composite baking technology in Africa. Industrial utilisation of plantain and banana flour may reduce importation of wheat grains and other related farinaceous products into Nigeria and other African countries while promoting nutrients required for vulnerable groups. Apart from its baking potentials and utilisation in the production of snacks, plantain flour is used extensively as a substitute for gari in the production of thick dough usually eaten with vegetable soup in many parts of Africa. Large scale production of plantain flour is anticipated to increase its utilisation due to availability in supermarkets, hotels, restaurants and may constitute an important export commodity in the future. This review is anticipated to contribute to accelerated industrial composite bread making in Nigeria and other developing countries.

Standards for cassava products and guidelines for export have been established, which includes roots, flour, starch and composite flour. There is need for the establishment of standards for plantain and banana fruits and their derivative products in order to harness industrial application and export potentials. To ensure compliance with government policy on composite bread, consumers of bread and other baked goods need to be educated on the nutritional, economic and social benefits of this technology. Effective surveillance by regulatory bodies is also important to ensure strict compliance. For instance, direct inclusion of plantain, cooking banana and banana flour into wheat for supply to bakers should be ensured. It is also important that bakers take into consideration the need to diversify bread types in order to satisfy the needs of different consumers, knowing that Africa, like the rest of the world, is a cosmopolitan region. 


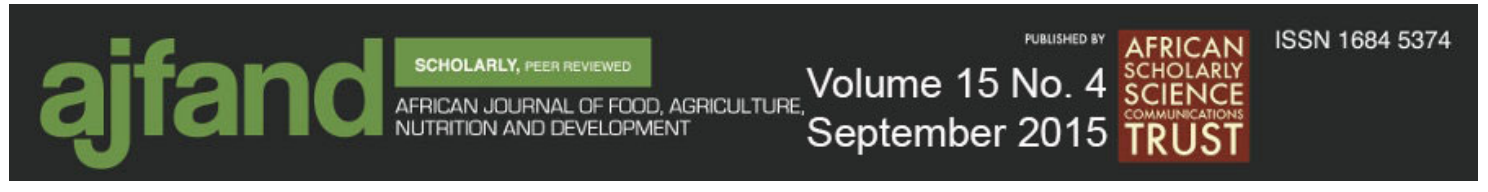

\section{REFERENCES}

1. Ogazi PO Plantain: production, processing and utilisation. Paman Associates Ltd., Aku-Okigwe, Okigwe, Imo State, Nigeria, 1996: 305.

2. Adeniji TA and CE Empere The development, production and quality evaluation of cake made from cooking banana flour. Global Journal of Pure and Applied Sciences 2001; 7: 633-635.

3. Olaoye OA, Onilude AA and OA Idowu Quality characteristics of bread produced from composite flours of wheat, plantain and soybeans. African Journal of Biotechnology, 2006; 5 (11): 1102-1106.

4. Mepba HD, Eboh $L$ and SU Nwaojigwa Chemical composition, functional and baking properties of wheat-plantain composite flours. African Journal of Food, Agriculture, Nutrition and Development, 2007; 7(1):1-22.

5. Hoseney RC Principles of cereal science and technology, $2^{\text {nd }}$ edition, American Association of Cereal Chemists, Inc., St. Paul, Minnesota, USA, 1994: 378.

6. Encyclopedia Americana Grohier Incorporated, USA, 1995: 480-488.

7. Encyclopedia Britanica $15^{\text {th }}$ Edition, Micropedia ready reference Encyclopedia, Britanica Inc., 1995: 490.

8. Akobundu CO The Utilization of Cassava flour in Composite Formula for bread making. HND Project 1989, Department of Food Science, Federal Polytechnic, Bauchi, Nigeria.

9. Wekhe SN and EB Banigo Small-scale bread making. In: (Wekhe, S.N. and Ochonma, V., eds.). Business Projects in Agriculture, Rivers State Newspaper Corporation, 1994, Port Harcourt, Nigeria, 81-85.

10. Hopkins AG Review: Micro-Economic History in Nigeria. The Journal of African History, Cambridge University Press, 1967; 8 (3): 567-568.

11. Dendy DAV, Clarke PA and AW James The use of blends of wheat and nonwheat flours in bread making. Tropical Science 1970; 12: 131-142.

12. FAO. Wheat importation in Nigeria in 2010. FAO Statistics 1999-2010. Food and Agriculture Organisation of the United Nations, Rome, 2010.

13. Poehlman JM Breeding Field Crops. Holt, Rinehart and Winston, Inc., New York, USA, 1959: 427.

14. Palmer JJ How to Brew. Defenestrative Pub Co. 2001: 233, ISBN 0-9710579$0-7$. 


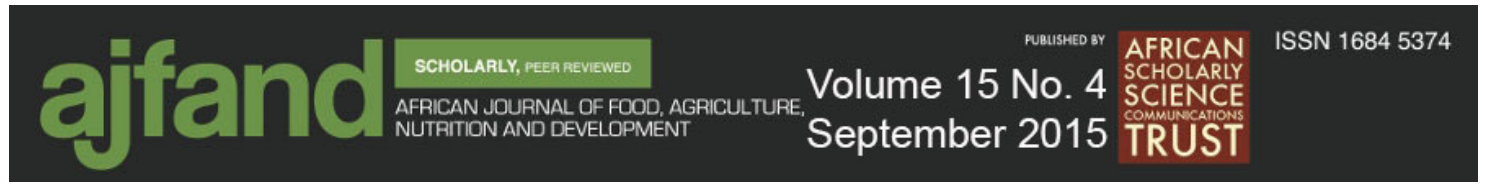

15. Neill R Booze: The Drinks Bible for the $21^{\text {st }}$ Century. Octopus Publishing Group, Cassell Illustrated, 2002: 112, ISBN 1-84188-196-1.

16. Gibson RS Zinc nutrition in developing countries. Nutrition Research Reviews, 1994, 7: 151-173.

17. Bouis HE, Graham RD and RM Welch The Consultative Group on International Agricultural Research (CGIAR) Micronutrients Project: Justification and objectives. United Nations University Food and Nutrition Bulletin 2000; 21 (4): 374-381.

18. Shrimpton $\mathbf{R}$ Community participation in food and nutrition programs: an analysis of recent government experiences. In: P. Pinstrup-Anderson, D. Pelletier and H. Alderman, (eds.). Child Growth and Nutrition in Developing Countries, Ithaca: Cornell University Press, 1995: 243-261.

19. Berg $H$ van den, Faulks R, Granado HF, Hirschberg J, Olmedilla B, Sandmann G, Southon S and W Stahl Review: The potential for the improvement of carotenoid levels in foods and the likely systemic effects. Journal of the Science of Food and Agriculture 2000; 80: 880-912.

20. United States Department of Agriculture. Nutrient Data Laboratory; 2012.

21. Engelberger L, Aalbersberg W, Ravi P, Bonnin E, Marks GC, Fitzgerald MH and $\mathbf{J}$ Elymore Further analyses on Micronesian banana, taro, breadfruit and other foods for provitamin A carotenoids and minerals. J. Food Comp Anal, 2003b; 16 (2): 219-236.

22. Engelberger L, Schierle J, Marks GC and MH Fitzgerald Micronesian banana, taro, and other foods: newly recognized sources of provitamin A and other carotenoids. J. Food Comp Anal, 2003a; 16 (1): 3-19.

23. Rodriguez-Amaya DB Carotenoids and food preparation: The retention of provitamin A carotenoids in prepared, processed, and stored foods. Opportunities for Micronutrient Intervention (OMNI), Arlington, 1997.

24. Pacheco-Delahaye E, Maldonado R, Perez E and M Schroeder Production and characterization of unripe plantain (Musa paradisiacal L.) flour. Interciencia 2008; 33: 290-296.

25. FAO. Fertilizer and plant nutrition. FAO Bulletin No. 3. Food and Agriculture Organisation of the United Nations, Rome, 2004.

26. World Bank. Africa can help feed Africa: Removing barriers to regional trade in food staples, 2012.

27. Swennen R Plantain cultivation under West African conditions: a reference manual. IITA Ibadan, Nigeria, 1990b. 


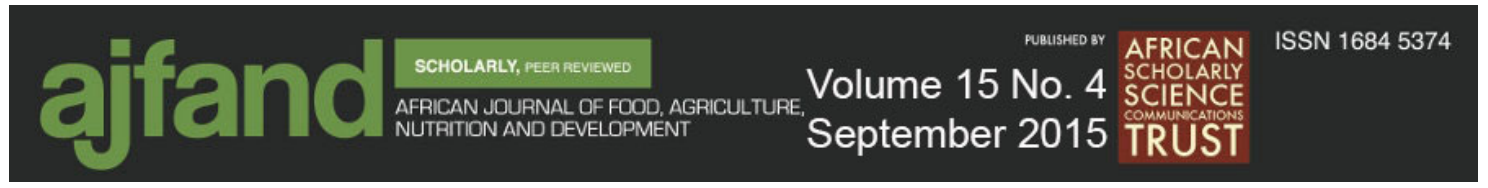

28. FAO. Food Outlook. Food and Agriculture Organisation of the United Nations, May, FAO, Rome, 1979.

29. Eggleston G, Omoaka PE and DO Ihedioha Development and evaluation of products from cassava flour as new alternatives to wheaten breads. J Sci Food Agric 1993; 59: 377-385.

30. Potter NN Food Science. Fourth Edition, Van Nostrand Reinhold Publishers, 1986; 115 Fifth Avenue, New York, New York 10003, 735.

31. Casier JPJ and G De Paepe Einfluss der wasser-löslichen Weizen und Roggenpentosane auf die Backeigenschaften von Weizenmehlen und anderen Rohstoffen. Gertreide Mehl Brot 27 1973; 36-44.

32. Barimalaa IS Processing and utilisation of bambara groundnut (Vigna subterranean). $\mathrm{PhD}$ Thesis, 1998, Rivers State University of Science and Technology, Port Harcourt, Nigeria, 216.

33. Folayan JA and JO Bifarin Economic analysis of plantain processing industry in Akure South Local Government Area of Ondo State. J. Agric. Extension Rural Dev. 2011; 3(4): 77-81.

34. FIIRO. Industrial profile on plantain flour production. Federal Institute of Industrial Research, Oshodi, Nigeria, 2009.

35. Ayodele $\mathbf{O H}$ and VG Erema Glycemic indices of processed unripe plantain meals. African Journal of Food Science and Technology 2010; 4: 514-521.

36. Zakpaa HD, Mak-Mensah EE and $\mathbf{J}$ Adubofour Production and characterisation of flour produced from ripe "apem” plantain (Musa sapientum) L. var. Paradisiacal; French horn) grown in Ghana. J. Agric. Biotechnol, Sustain. Dev. 2010; 2: 92-99.

37. Aina OS, Ajijola S, Bappah MT, Ibrahim I and IA Musa Economic analysis if plantain marketing in Odigbo Local Government Area of Ondo State, Nigeria. Global Advanced Research Journal of Agricultural Science 2012; 1(5): 104-109.

38. Oluwatomiwa TA Economic analysis of plantain in Ondo West and Ondo East Local Government Area of Ondo State. Unpublished MSc Agricultural Economic Thesis, University of Ibadan, Nigeria, 2008.

39. Bamidele EA, Cardoso AO and O Olaofe Rheology and baking potential of wheat/plantain composite flour. Journal of the Science of Food and Agriculture 1990; 51 (3): 421-424. 


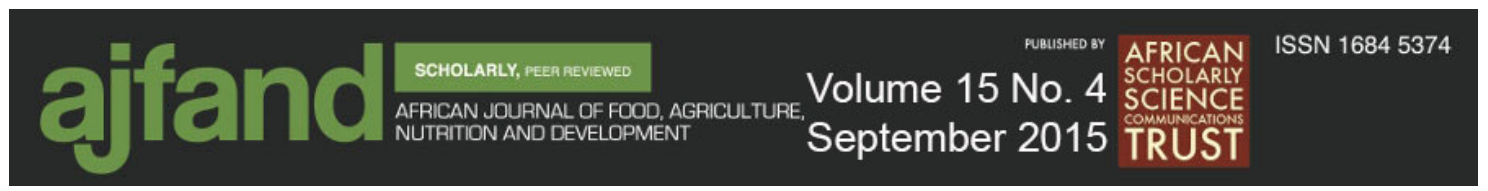

40. Sarawong C, Gutierrez ZR, Berghoef E and R Schoenlechner Effect of green plantain flour addition to gluten-free bread and resistant starch content. International Journal of Food Science and Technology 2014; DOI: 1111/ijfs.12491.

41. Onwulata C, Thomas-Gahring A, Oduro-Yeboah C, White AK and AT Hotchkiss Effects of uniquely processed cowpea and plantain flours on wheat bread properties. Journal of Food processing and preservation 2014; DOI: 10. 1111/jfpp.12246: 1-10.

42. Oluwalana IB and MOS Oluwamukomi Proximate composition, rheological and sensory qualities of plantain (Musa paradisiaca) flour blanched under three temperature regimes. African Journal of Food Science 2011; 5: 769-774.

43. Adeniji TA, Sanni LO, Barimalaa IS and AD Hart Nutritional and antinutritional composition of flour made from plantain and banana hybrid pulp and peel mixture. Nigerian Food Journal 2007; 25: 68-76.

44. Ehirim FN and MC Umelo Supplementary effect of plantain flour on dough characteristics and bread quality. European International Journal of Applied Science and Technology 2014; 1(2): 61-73.

45. Adepoju OT, Sunday BE and OA Folaranmi Nutrient composition and contribution of plantain (Musa paradisiacea) products to dietary diversity of Nigerian consumers. African Journal of Biotechnology 2012; 11(71): 1360113605.

46. Eke-Ejiofor $\mathbf{J}$ and DB Kiin-Kabari Effects of substitution on the functional properties of flour, proximate and sensory properties of wheat/plantain composite bread. International Journal of Agricultural Sciences 2012; 2(10): 281-284.

47. Phillip B, Shittu AM, Aiyelaagbe IOO and T Adedokun Economic potentials of plantain and banana and fluted pumpkin intercropping as a poverty reduction strategy in south-western Nigeria. World Journal of Agricultural Science 2009; 5(5): 525-534.

48. Juarez-Garcia E, Agama-Acevedo E, Sa'Yago-Ayerdi SG and SL Rodri'guez-Ambriz Composition, Digestibility and Application in Bread making of Banana Flour. Plant Foods for Human Nutrition 2006; 61: 131-137.

49. Thorne MJ, Thompson LU and DJ Jenkins Factors affecting starch digestibility and the glycemic response with special reference to legumes. Am J Clin Nutr. 1983; 38: 481-488.

50. Jenkins DJA, Kendall CWC, Marchie A and LSA Augustin The glycaemic index: an overview of its possible role in the prevention and treatment of chronic disease. Int J Clin Pract, 2004, 58 (Suppl. 142): 3-7. 


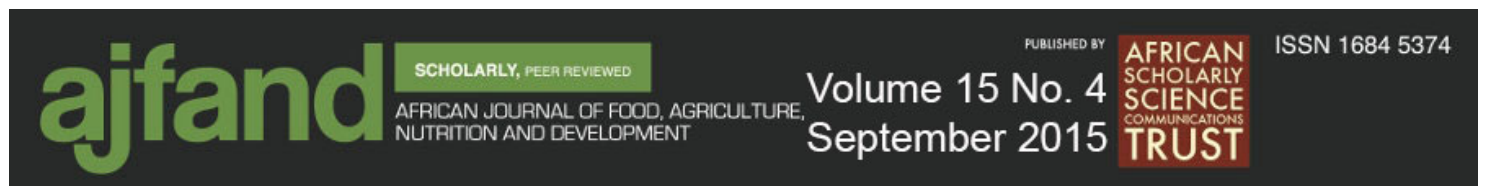

51. Ludwig DS The glycemic index: physiological mechanisms relating to obesity, diabetes, and cardiovascular disease. JAMA 2002; 287: 2414-2423.

52. Rasmussen O Day-to-day variation of the glycemic response in subjects with insulin-dependent diabetes with standardized pre-meal blood glucose and prandial insulin concentrations. Am. J. Clin. Nutr. 1993; 57: 908-911.

53. Ludwig DS, Majzoub JA and A Al-Zahrani High glycemic index foods, overeating and obesity. Pediatrics 1999; 103: E26.

54. Saifullah R, Abbas FMA, Yeoh SY and ME Azhar Utilisation of green banana flour as a functional ingredient in yellow noodle. International Food Research Journal 2009; 16: 373-379.

55. Aparicio-Saguilan A, Sayago-Ayerdi Sonia G, Vargas-Torres, Apolonio, Tovar Juscelino, Ascencio-Otero, Tania E andllo-Perez and A Luis Slowly digestible cookies prepared from resistant starch-rich lintnerized banana starch. Journal of Food composition and Analysis 2007; 20: 175-181.

56. Rungsinee $\mathbf{S}$ and $\mathbf{P}$ Natcharee Oxygen permeability and mechanical properties of banana films. Food Research International 2007; 40: 365-370.

57. Foster-Powell K, Holt SHA and JC Brand-Miller International Table of glycemic index and glycemic local values. Am. J. Clin. Nutr. 2002; 76: 5-56.

58. Adepoju OT, Adekola YG, Mustapha SO and SI Ogunola Effect of processing methods on nutrient retention and contribution of cassava (manihot spp) to nutrient intake of Nigerian consumers. Afr. J. Food Agric. Nutr. Dev. 2010: 2099-2111.

59. Abiodun OA and RO Adeleke Effect of partially defatted soybean flour substitution on the proximate, pasting and sensory properties of banana flour. African Journal of Agricultural Research 2010; 5(13): 1696-1700.

60. Foluso A Ajala $\mathbf{L}$ and $\mathbf{T}$ Ibrahim Effect of the addition of defatted okra seed (Abelmoschus esculentus) flour on the chemical composition, functional properties and Zn bioavailability of plantain (Musa paradisiacal Linn) flour. Journal of Microbiology, Biotechnology and Food Sciences 2012; 2(1): 69-82.

61. Ebiringa DC and SI Echebiri Effects of substituting honey for sucrose in breadmaking. Nigerian Food Journal 2004; 22: 189-194.

62. Okaka JC and MI Isieh Development and quality evaluation of cow-pea wheat biscuits. Nigerian Food Journal 1990; 8: 56-62. 
63. Baiyeri TG Evaluation of multi-mixes and porridges made from maize (Zea mays), soybean (Glycine max) and plantain (landrace and hybrid Musa AAB) flour for use as complementary food. MSc. Thesis 2004, Department of Home Science, Nutrition and Dietetics, University of Nigeria, Nsukka, Nigeria, 71.

64. Sanni SA and SA Eniola Sensory characteristics of plantain-wheat biscuits. In: G.O. Adegoke, L.O. Sanni, K.O. Falade and P.I. Uzo-Peters (eds.). Proceedings of the $28^{\text {th }}$ Annual Conference/AGM Nigerian Institute of Food Science and Technology, University of Ibadan, Ibadan, Nigeria, 2004; 12-14 October, 2004.

65. Chukwu U, Olorunda AO, Adeniji TA, Amos $\mathbf{N}$ and RSB Ferris Development, production properties and acceptability of snacks and weaning food made from extruded cooking banana (ABB). In: (R.S.B. Ferris, ed.). Postharvest Technology and Commodity Marketing. Proceedings of a Postharvest conference on technology and commodity marketing in West Africa, 29 Nov.-1 Dec. 1995, Accra, Ghana, 1998. Published by the International Institute of Tropical Agriculture (IITA), Ibadan, Nigeria, 120-131.

66. Akubor PI Functional properties of cowpea-plantain flour blends. Proceedings of $22^{\text {nd }}$ Annual Conference, Nigerian Institute of Food Science and Technology. University of Agriculture, Abeokuta, Nigeria, 1989. 